\title{
Markers of adventitious root formation
}

\author{
GJ De Klerk \\ Centre for Plant Tissue Culture Research, PO Box 85, 2160 AB Lisse, the Netherlands
}

(Received 30 July 1996; accepted 23 September 1996)

\begin{abstract}
Summary - This article deals with markers for rootability of cuttings and markers for the successive phases in adventitious root formation. Since rootability depends on the ontogenetic, developmental and physiological state of the cuttings, markers for these states may be used as markers for rootability. For example, morphological characteristics that indicate the adult state, also indicate low rootability. For the phases in adventitious root formation, physiological parameters are reliable markers, in particular transient sensitivity to plant growth regulators applied as a pulse. The reliability of biochemical markers, in particular changes in peroxidase activity, is disputed. Molecular markers may be obtained from very sensitive screening techniques, from mutant-studies or from studies that do not deal with adventitious root formation, eg, research on auxin action, cell cycle activation or meristem organization. On the molecular level, research has started only recently. Molecular markers will require validation by physiological and histological studies.
\end{abstract}

auxin / peroxidase / regeneration / rootabilty / marker

Résumé - Marqueurs de la formation de racines adventives. Cet article traite des marqueurs d'enracinement des boutures et des phases successives de formation des racines adventives. Comme l'aptitude à former des racines dépend de l'état ontogénique, du développement et de la physiologie des boutures, des marqueurs de ces états peuvent être utilisés pour l'enracinement. Ainsi, des caractéristiques morphologiques indiquant le stade adulte traduisent une faible aptitude à la formation des racines. Pour la phase de formation des racines adventives, des paramètres physiologiques sont des marqueurs fiables, en particulier la sensibilité passagère à l'application des régulateurs de croissance apportés «en pulse». La fiabilité des marqueurs biochimiques, en particulier les changements dans l'activité péroxidase, sont contestés. Des marqueurs moléculaires peuvent être obtenus à partir de techniques très sensibles, d'étude de mutants ou des travaux ne concernant pas la phase de formation des racines adventives, par exemple les recherches sur l'action des auxines, l'activation du cycle cellulaire et l'organisation du méristème. La recherche de marqueurs moléculaires est récente; ceux-ci doivent être validés par des études physiologiques et histologiques.

auxine / péroxidase / régénération / enracinement / marqueur

\section{INTRODUCTION}

A marker is a parameter that shows sufficient (preferably $100 \%$ ) coincidence with a certain physiological, developmental or genetic state. Usually, markers are on the biochemical or mole- cular level. Thus, proline accumulation is a marker of drought stress (Hanson and Hitz, 1982), storage protein synthesis of zygotic, somatic or microsporic embryo maturation (Crouch, 1982) and glucuronidase activity of transformation. On other levels, useful parameters may also be 
found. Root formation after application of auxin is a physiological marker for the ontogenetic (juvenile vs adult) state (Zimmerman et al, 1985). On the histological level, the presence of two opposite meristems connected by vascular tissue is a marker of a (somatic) embryo. Leaf shape is a morphological marker of the ontogenetic state (Zimmerman et al, 1985).

In adventitious root formation (ARF), markers may be used in various ways. Markers for rootability predict the success of a rooting treatment and have therefore a great practical importance. Since the various phases in ARF often have different hormonal requirements, markers are required to identify the beginning and end of the phases. Markers for the phases in ARF may also be used to establish in which phase recalcitrant cuttings become inhibited. Finally, markers may also provide an understanding of the underlying mechanisms in ARF.

The present article deals with histological, morphological, physiological, biochemical and molecular parameters studied in relation with rootability and the successive phases in ARF, and discusses their use as markers.

\section{PITFALLS IN MARKER STUDIES}

The degree of coincidence of a marker with a certain state determines its usefulness. To validate a marker, conditions must be created under which the state occurs to a different extent. In studies on markers of the phases in ARF, for example, conditions must be imposed that alter the rooting response (eg, besides auxin another inhibitory plant growth regulator may be added). The marker should show the appropiate change. For most markers discussed here, such analysis has not been carried out.

A second pitfall concerns markers for regeneration specifically. In the examples cited in the previous section, most or a large portion of the analysed tissue is in the state for which the marker is characteristic. However, in regeneration processes the situation is different because the number of cells that participate in regeneration processes is very small. For example, in $1 \mathrm{~mm}$ stem slices cut from apple microcuttings, ARF starts from a few cells in the primary rays between the vascular bundles three cell layers from the basal cutting surface (Jasik and De Klerk, 1997). At $72 \mathrm{~h}$ after the start of the rooting treatment, the time at which the meristemoids are being formed, the volume of a meristemoid is ca
$0.001 \mathrm{~mm}^{3}$. The volume of a slice is ca $1 \mathrm{~mm}^{3}$. Thus, ten meristemoids (per slice five to ten roots are formed) account for $1 \%$ of the volume of a slice. Obviously, biochemical and molecular characteristics of the cells in the meristemoids are swamped by the other cells that account for $99 \%$ of the volume. Perhaps advanced techniques that may distinguish minor differences, eg, mRNA differential display, are successful. In embryogenesis from microspores in Brassica, as much as $30 \%$ of the cells may be involved in regeneration (Custers et al, 1994). In such a system, regeneration-related genes are more easily identified. For rooting, a similar system does not exist.

\section{MARKERS FOR ROOTABILITY}

In ARF, meristem formation is likely initiated from specific cells only (De Klerk et al, 1997a). As noted earlier, molecular and biochemical characteristics of these few cells will be swamped by the large number of surrounding cells. However, molecular and biochemical analyses may still be helpful: Since rootability differs greatly among cuttings with various developmental, physiological or genetic states, parameters characteristic for these states may be used as markers for rootabilty.

Adventitious roots easily regenerate from juvenile tissue. Thus, markers for rootability are to some extent the same as markers for the juvenile state. Markers for juvenility include morphological characteristics (Zimmerman et al, 1985), phenolic compounds (Girouard, 1969; Vieitez et al, 1987; Jay-Allemand et al, 1988), abscissic acid level (Noiton et al, 1992) and specific mRNA species (Murray et al, 1994; Woo et al, 1994).

Besides changes in the ontogenetic state, tissues may also show various other developmental changes such as chronological ageing (as opposed to ontogenetic ageing), dormancy development and rhythmic growth. These changes may cause variation in rootability during a growing season (Howard, 1996). In cuttings with different developmental or physiological states, it has been observed that rootability coincides with a high level of indoleacetic acid (IAA) (Weigel et al, 1984; Blakesley et al, 1991) and with specific phenolic compounds (Curir et al, 1990, 1993). Rhythmic growth (El-Morsy and Millet, 1996) and dormancy development (De Klerk and Gerrits, 1996) also occur in tissue culture and likely cause the large differences in 
rootability among microcuttings from different subcultures (Denissen et al, 1992), among microcuttings of a single batch and among stem slices taken from the same cutting (De Klerk and Caillat, 1994). An example of the relation between rootability of individual microcuttings and a biochemical parameter (peroxidase activity) is shown in figure 1.

There have been several examinations on closely related genotypes that differ in rootability. Differences include the degree of sclerification of the primary phloem (Beakbane, 1961), endogenous IAA levels (Alvarez et al, 1989) and peroxidase activity (Gus'kov et al, 1989).

In conclusion, morphological, biochemical and molecular parameters characteristic for the ontogenetic state may be used as markers for rootability. However, their use is limited. For example, in Hedera the leaf shape is a reliable marker for the ontogenetic state but this does not mean that all cuttings with juvenile leaves develop adventitious roots after the proper stimulus has been given. For other developmental and physiological states that influence rootability, markers may be developed. Possibly, ARF depends on the occurrence of a specific cell type from which roots always develop when the proper stimulus is given. If such a cell type occurs, specific molecular probes may be identified.

\section{MARKERS FOR THE PHASES IN ADVENTITIOUS ROOT FORMATION}

\section{Physiological markers}

Christianson and Warnick (1983) concluded that regeneration consists of three successive phases: i) dedifferentiation during which cells become competent to respond to the organogenic or embryogenic stimulus, ii) induction during which the stimulus acts and the cells become committed to a developmental pathway and iii) differentiation during which the stimulus is no longer required and the previously determined cells form the organ/embryo. These authors established the beginning and end of the phases in shoot regeneration using differences in sensitivity of the three phases to added hormones. A similar study was conducted by our group for rooting. By giving pulses with benzylaminopurine (BAP, which may be considered as an auxin antagonist), indolebutyric acid (IBA), p-chlorophenoxyisobutyric acid (PCIB, an anti-auxin) and salicylic acid (SA, a monophenol that stimulates (AA-oxidase), the timing of the three phases was determined in shoots and stem slices of the apple rootstock 'Jork 9' (De Klerk, 1995; De Klerk et al, 1995, 1997b). Results with BAP and SA pulses are shown in figure 2. Other authors have reported similar results (Mitsuhashi et al, 1969; Attfield and Evans, 1991; Burritt and Leung, 1996).

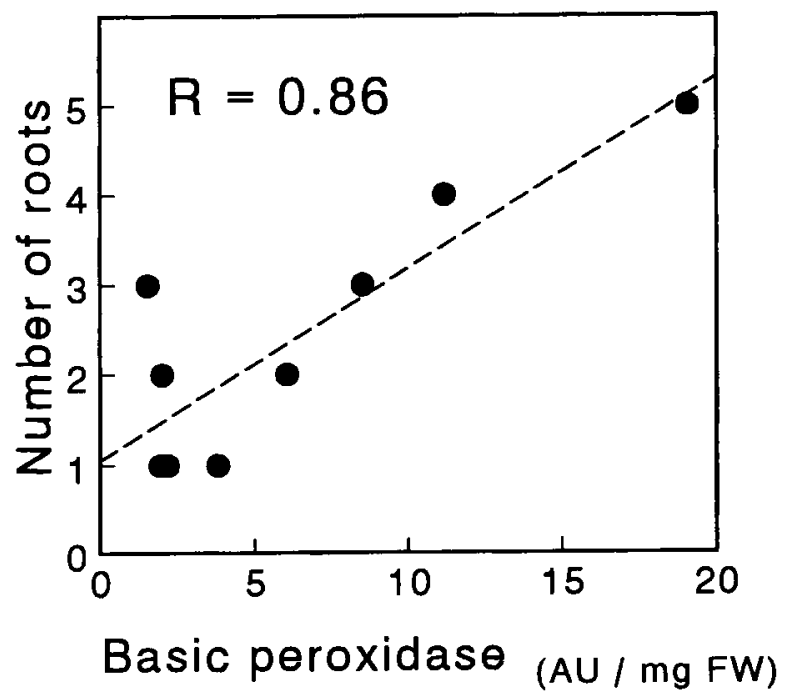

Fig 1. The number of roots regenerated from an apple microcutting plotted against the activity of a basic peroxidase component at the time of transfer to rooting medium. The basic peroxidase activity was determined in a $1 \mathrm{~mm}$ slice excised from the basal end of the microcutting (redrawn from De Klerk et al, 1990).

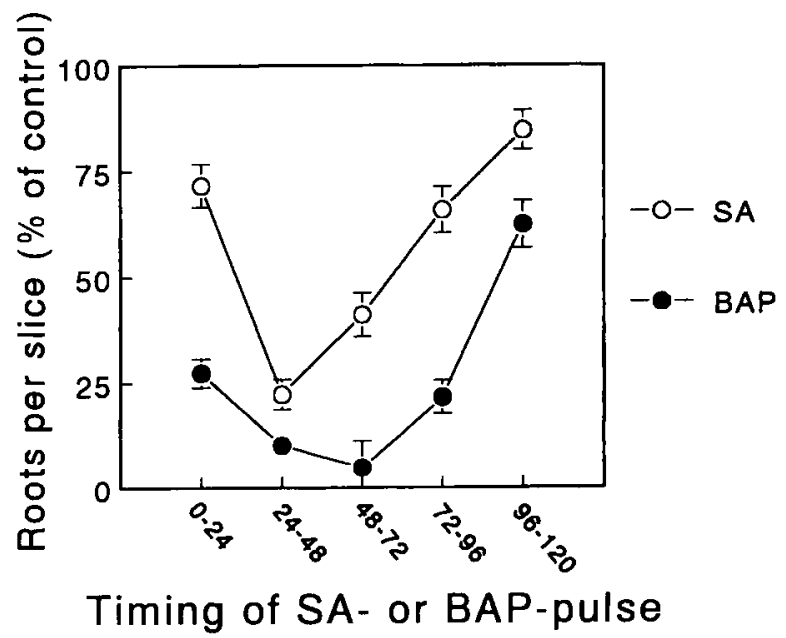

Fig 2. Effect of $24 \mathrm{~h}$ salicylic acid (SA) or benzylaminopurine (BAP) pulses given during the first 5 days of adventitious root formation in $1 \mathrm{~mm}$ thick apple-stem slices. Slices were cultured for 5 days on medium containing $100 \mu \mathrm{M}$ indoleacetic acid (IAA) (SA pulses) or $3 \mu \mathrm{M}$ indolebutyric acid (IBA) (BAP pulses). They were then transferred to hormone-free medium for 16 days. BAP $(0.3 \mu \mathrm{M})$ or $\mathrm{SA}(100 \mu \mathrm{M})$ were added during the indicated periods (in hours). During the SA or BAP pulses, $100 \mu \mathrm{M}$ IAA or $3 \mu \mathrm{M}$ IBA were also present in the medium. The root number is expressed as a percent of the control. The experiments with BAP and SA pulses were carried out with two batches of 'Jork 9 ' microcuttings obtained in different subcultures. 
The studies cited here show that a transiently increased sensitivity to plant growth regulators provides a reliable marker for the successive phases in regeneration. However, physiological markers have a limited use. Since they are only applicable when the cuttings are capable of rooting, physiological markers cannot be used to monitor in which phase recalcitrant cuttings become inhibited.

\section{Histological markers}

From numerous histological examinations on ARF, a general pattern can be deducted (Lovell and White, 1986). After auxin application, specific cells are activated. Then, after several cell divisions, a meristemoid is formed and subsequently a root primordium with a typical dome-shape. Histological studies indicate at what time recalcitrant cuttings become inhibited. Occurrence of cell divisions in stems without subsequent root formation is reported in several studies. For example, a tobacco mutant that is unable to form root meristemoids shows intially 'normal' cell divisions in response to auxin (Lund et al, 1996). A major problem in histological studies is that the physiological state cannot be derived from the observations until the typical root primordium has been formed. In particular, it is not known whether cells in a meristemoid are already committed to root formation or whether the commitment occurs before or after meristemoid formation. (The term 'commitment' is used in the physiological sense: after the cells have developed commitment to root formation, they no longer require the rhizogenic stimulus.) Recently, it was shown in 'Jork 9' microcuttings and stem slices that the commitment to root formation develops during meristemoid formation (see earlier; De Klerk et al, 1995; Jasik and De Klerk, 1997). Another disadvantage of histological studies is that they are very laborious. Since from a population a sufficiently large sample has to be taken, in each experiment large numbers of cuttings ( $>50$ ) have to be analysed.

In few histological studies, the cells that participate in ARF have been analysed on the biochemical or molecular levels. In $1 \mathrm{~mm}$ stem slices cut from 'Jork 9' microcuttings, Jasik and De Klerk (1997) found during the first $24 \mathrm{~h}$ of exposure to auxin an increase in starch grains in specific cells (fig 3 ). This is before the induction phase begins. Thus, the accumulation of starch grains may be a marker for the dedifferentiation phase. After $24 \mathrm{~h}$, these starch grains are degraded rapidly and the cells enter cell division. From some of these cells, root meristemoids develop. The increase and decrease of starch only occurs in the presence of IBA. In the apple stem slices, other correlations between starch and rooting have not yet been examined. In excised mung bean hypocotyls, many cells throughout the stem are activated as shown by the incorporation of labelled thymidine (also in the upper part where no or only few roots are formed). Activation occurs more rapidly in hypocotyls exposed to auxin (Tripepi et al, 1983). A third example is on Hedera. Chronologically young, mature petiole explants show a decrease of a mRNA for a proline-rich protein in specific cells from which the root meristemoids will develop. Such a decrease does not occur in chronologically old, mature petioles that are incapable of root formation (Sanchez et al, 1995).

\section{Biochemical markers}

Many studies deal with biochemical changes in cuttings during ARF. A characteristic course of the activity of basic peroxidase has been reported by several researchers: after excision of a cutting, peroxidase activity increases sharply, then decreases and subsequently gradually increases (for review see Gaspar et al, 1992). The decrease of peroxidase activity supposedly coincides with the initiation of cell division. Figure 4 shows the course of peroxidase activity during ARF in Sequoiadendron shoots and figure 5 the results of an experiment in which the value of the peroxidase peak is associated with rooting of

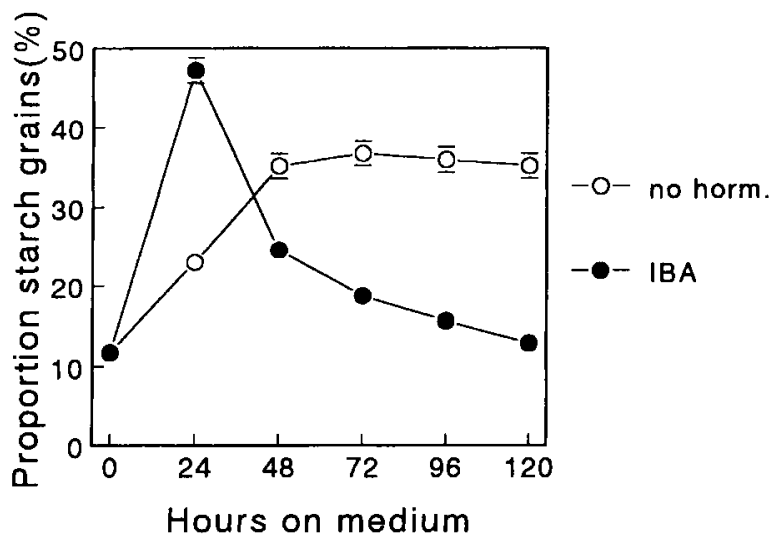

Fig 3. Proportion of starch grains in cells of the cambial region in the basal part of $1 \mathrm{~mm}$ thick apple-stem slices. The proportion of starch grains is given as a percent of plastid area. The slices were cultured with (O) or without (O) $3 \mu \mathrm{M}$ indolebutyric acid (IBA) (redrawn from Jasik and De Klerk, 1997). 
Cynara shoots rejuvenated by repeated subcultures. Some authors, however, did not observe the characteristic course but a continuous increase of peroxidase activity (Pythoud and Buchala, 1989; De Klerk et al, 1990). Several conditions have been created by which the rooting performance decreases. Sometimes the expected reduction of the peroxidase peak occurs (Moncousin and Ducreux, 1984), but in other cases not (Gus'kov et al, 1989; De Klerk et al, 1990). It may be that the characteristic changes in peroxidase activity is caused by auxin and is not related to rooting. The evolution of peroxidase with 2,4-dichlorophenoxyacetic acid (2,4D), an auxin that induces only very few root meristems (De Klerk et al, 1997c), has not been examined.

Hormone levels, in particular IAA levels, constitute another possible biochemical marker for the phases in ARF. It has been reported that during ARF, IAA levels show the opposite course of peroxidase (fig 4; see also Moncousin et al, 1989). The inverse relationship between the endogenous IAA level and peroxidase activity may be explained by the fact that basic peroxidases likely oxidize IAA. It has not been determined whether the characteristic changes in endogenous IAA levels also occur independently of the rooting event. A complicating factor is that these studies are usually performed in IBA-treated cuttings. Applied IBA is metabolized into IAA (Van Der Krieken et al, 1993) and probably functions as a slow-release source of IAA.

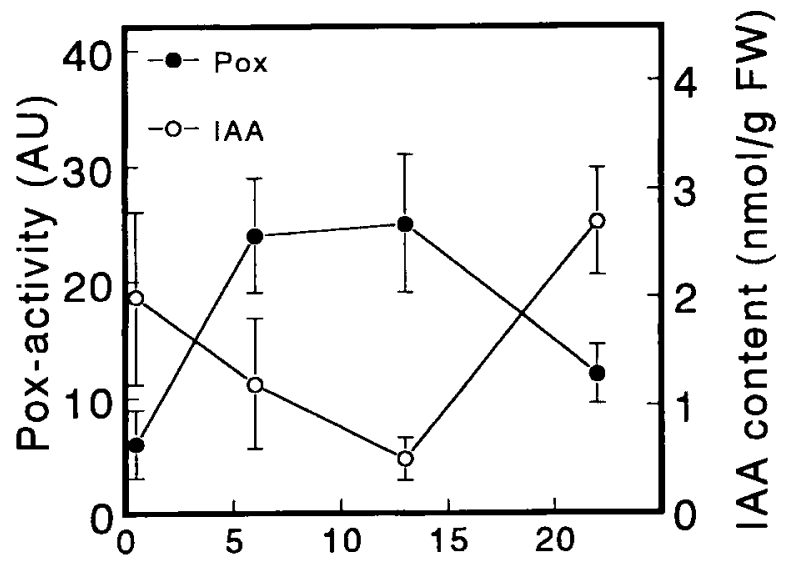

\section{Days on rooting medium}

Fig 4. Peroxidase (Pox) activity and indoleacetic acid (IAA) level in Sequoiadendron giganteum shoots during adventitious root formation. The shoots were on medium with 1 mg. $L^{-1}$ naphthaleneacetic acid for 13 days, and subsequently transferred to medium without auxin and cultured for another 15 days. The complete shoot was extracted for the determinations (redrawn from Berthon et al, 1989).
Other compounds that show a characteristic course during ARF are ethylene (Moncousin et al, 1989; Hausman, 1993) and polyamines (Torrigiani et al, 1989; Hausman et al, 1994), but again in all cases it has not been properly examined whether the changes only occur in tissues in which ARF takes place.

Based on early, promising observations, many examinations have been carried out on biochemical markers for the phases in ARF, in particular on peroxidases. Occasionally, these markers have been used. For example, Berthon et al (1987) used the timing of the peroxidase peak to establish the time at which the shoots have to be transferred from an inductive to an expressive medium. Although the early findings have been confirmed, numerous exceptions occur. Particularly when conditions are created that do not allow ARF, the markers often do not show the appropiate changes. This puts into question the reliability of these markers.

\section{Molecular markers}

There are several approaches to study adventitious rooting on the molecular level. First, mRNA populations or newly synthesized proteins may be studied in cuttings that root and cuttings that are incapable of rooting, eg, by not supplying them with auxin. In this way, Dhindsa et al (1987) studied newly synthesized proteins and mRNAs in a cell-free protein synthesizing system. mRNA

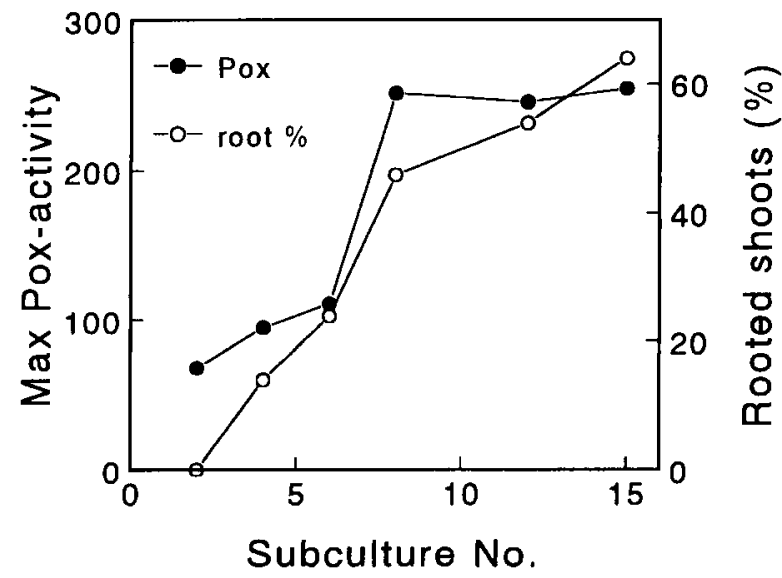

Fig 5. Maximal level of peroxidase (Pox) activity and rooting performance of Cynara scolymus shoots subcultured for increasing times. Cultures of Cynara were initiated from buds and subcultured at 8 week intervals. At the indicated subculture numbers, shoots were transferred to rooting medium, and both the rooting percentage and the maximal value of peroxidase activity during the rooting treatment were determined. For the peroxidase determination, the complete shoot was extracted (drawn from data of Moncousin and Ducreux, 1984). 
populations have recently been examined with the differential display technique (Diaz-Sala et al, 1996). These studies suffer from the fact that only very few cells participate in the rooting process.

Second, probes that have been isolated in other studies, eg, probes related to auxin application, meristem organization or cell cycle (Hemerly et al, 1993) may be studied in cuttings during ARF.

Third, in a population of mutated plants (Arabidopsis seedlings) mutants incapable of ARF may be selected. Subsequently, the gene that has been mutated can be isolated. Such a study has recently been reported for lateral root primordia (Smith and Fedoroff, 1995). The identified gene was also a marker for adventitious root primordia.

Molecular studies have only been initiated recently. Their great advantage is their sensitivity. It is likely that the molecular studies will result in specific markers for the phases in ARF.

\section{CONCLUSION}

The various techniques used to root cuttings have been developed some 60 years ago (De Klerk and Ter Brugge, 1992). Ever since, there has been little or no progress in spite of the vast basic and applied research. Recently, however, progress has been made in the understanding of ARF. In particular, it has been shown that ARF is a process consisting of distinct phases, and physiological markers of these phases have been developed. In addition, molecular studies have been started. The development of molecular markers for the phases of rooting will allow us to establish when the block in recalcitrant cuttings occurs. These new developments may result in new rooting treatments.

\section{ACKNOWLEDGMENTS}

I wish to thank M Langens-Gerrits for the critical reading of the manuscript.

\section{REFERENCES}

Alvarez R, Nissen SJ, Sutter EG (1989) Relationship between indole-3-acetic acid levels in apple (Malus pumila Mill) rootstocks cultured in vitro and adventi- tious root formation in the presence of indole-3butyric acid. Plant Physiol 89, 439-443

Attfield EM, Evans PK (1991) Stages in the initiation of root and shoot organogenesis in cultured leaf explants of Nicotiana tabacum cv Xanthi nc. J Exp Bot 42, 59-63

Beakbane AB (1961) Structure of the plant stem in relation to adventitious rooting. Nature 192, 954955

Berthon JY, Boyer N, Gaspar T (1987) Sequential rooting media and rooting capacity of Sequoiadendron giganteum in vitro. Peroxidase activity as a marker. Plant Cell Rep 6, 341-344

Berthon JY, Maldiney R, Sotta B, Gaspar T, Boyer N (1989) Endogenous levels of plant hormones during the course of adventitious rooting in cuttings of Sequoiadendron giganteum (Lindl) in vitro. Biochem Physiol Pflanz 184, 405-412

Blakesley D, Weston GD, Elliott MC (1991) Endogenous levels of indole-3-acetic acid and abscissic acid during the rooting of Cotinus coggygria cuttings taken at different times of the year. Plant Growth Regul 10, 1-12

Burritt DJ, Leung DWM (1996) Organogenesis in cultured petiole explants of Begonia x erythrophylla: the timing and specificity of the inductive stimuli. $J$ Exp Bot 47, 557-567

Christianson ML, Warnick DA (1983) Competence and determination in the process of in vitro shoot organogenesis. Dev Biol 95, 288-293

Crouch ML (1982) Non-zygotic embryos of Brassica napus $\mathrm{L}$ contain embryo-specific storage proteins. Planta 156, 520-524

Curir P, Van Sumere CF, Termini A, Barthe $P$, Marchesini A, Dolci M (1990) Flavonoid accumulation is correlated with adventitious root formation in Eucalyptus gunnii Hook micropropagated through axillary bud stimulation. Plant Physiol 92, 11481153

Curir P, Sulis S, Mariani F, Van Sumere CF, Marchesini A, Dolci M (1993) Influence of endogenous phenols on rootability of Chamaelaucium uncinatum Schauer stem cuttings. Sci Hort 55, 303-314

Custers JBM, Cordewener JHG, Nöllen Y, Dons HJM, Van Lookeren Campagne MM (1994) Temperature controls both gametophytic and sporophytic development in microspore cultures of Brassica napus. Plant Cell Rep 13, 267-271

De Klerk GJ (1995) Hormone requirements during the successive phases of rooting of Malus microcuttings. In: Current Issues in Plant Cellular and Molecular Biology (M Terzi, R Cella, A Falavigna, eds), Kluwer, Dordrecht, the Netherlands, 111-116

De Klerk GJ, Ter Brugge J (1992) Factors affecting adventitious root formation in microcuttings of Malus. agronomie 12, 747-755

De Klerk GJ, Caillat E (1994) Rooting responses of stem-disks excised from the same 'M9 Jork' microcutting. Adv Hort Sci 8, 15-18 
De Klerk GJ, Ter Brugge J, Smulders R, Benschop M (1990) Basic peroxidases and rooting in microcuttings of Malus. Acta Hort 280, 29-36

De Klerk GJ, Gerrits MM (1996) Development of dormancy in tissue-cultured lily bulblets and apple shoots. In: Plant Dormancy: Physiology, Biochemistry, and Molecular Biology (GA Lang, ed), CAB International, Wallingford, York, UK, 115-131

De Klerk GJ, Keppel M, Ter Brugge J, Meekes H (1995) Timing of the phases in adventitious root formation in apple microcuttings. $J$ Exp Bot 46, 965972

De Klerk GJ, Arnholdt-Schmitt B, Lieberei R, Neumann $\mathrm{KH}$ (1997a) Regeneration of roots, shoots and embryos: physiological, biochemical and molecular aspects. Biol Plant (in press)

De Klerk GJ, Marinova S, Rouf S, Ter Brugge J (1997b) Salicylic acid affects rooting of apple microcuttings by enhancement of oxidation of auxin. Acta Hort (in press)

De Klerk GJ, Ter Brugge J, Jasik J, Marinova S (1997c) Different efficacies of various auxins during the successive phases of the rooting process in apple microshoots. In: Biology of Root Formation and Development (A Altman, ed), Plenum, New York, NY, USA (in press)

Denissen CJM, De Klerk GJ, Albers MRJ, Ter Brugge J, Kunneman BPAM (1992) Effect of accidental factors on rooting of Malus. agronomie 12, 799-802

Dhindsa RS, Dong G, Lalonde L (1987) Altered gene expression during auxin-induced root development from excised mung bean seedlings. Plant Physiol $84,1148-1153$

Diaz-Sala C, Singer PB, Hutchinson KW, Greenwood MS (1996) Differential gene expression during maturation-caused decline in adventitious rooting ability in loblolly pine (Pinus taeda L). In: Second International Symposium on the Biology of Root Formation and Development. Book of Abstracts. Jerusalem, 4

El-Morsy AA, Millet B (1996) Rhythmic growth and optimization of micropropagation: the effect of excision time and position of axillary buds on in vitro culture of Citrus aurantium L. Ann Bot 78, 197-202

Gaspar T, Kevers C, Hausman JF, Berthon JY, Ripetti $V$ (1992) Practical uses of peroxidase activity as a predictive marker of rooting performance of micropropagated shoots. agronomie 12, 757-765

Girouard RM (1969) Physiological and biochemical studies of adventitious root formation. Extractible rooting cofactors from Hedera helix. Can J Bot 47, 687-699

Gus'kov AV, Tikhomirov IA, Polikarpova FY (1989) Peroxidase activity in apple clone stocks with different capacity for rhizogenesis. Fiziol Rast 35, 945954

Hanson AD, Hitz WD (1982) Metabolic responses of mesophytes to plant water deficits. Annu Rev Plant Physiol 33, 163-203
Hausman JF (1993) Changes in peroxidase acitivity, auxin level and ethylene production during root formation by poplar shoots raised in vitro. Plant Growth Regul 13, 263-268

Hausman JF, Kevers C, Gaspar T (1994) Involvement of putrescine in the inductive rooting phase of poplar shoots raised in vitro. Physiol Plant 92, 201206

Hemerly AS, Ferreira P, De Almeida Engler J, Van Montagu M, Engler G, Inzé D (1993) cdc2a expression in Arabidopsis is linked with competence for cell division. Plant Cell 5, 1711-1723

Howard BH (1996) Relationship between shoot growth and rooting of cuttings in three contrasting species of ornamental shrub. J Hort Sci 71, 591-405

Jasik J, De Klerk GJ (1997) Anatomical and ultrastructural examination of adventitious root formation in stem slices of apple. Biol Plant (in press)

Jay-Allemand C, Cornu D, Macheix JJ (1988) Biochemical attributes associated with rejuvenation of walnut tree. Plant Physiol Biochem 26, 139-144

Lovell PH, White J (1986) Anatomical changes during adventitious root formation. In: New Root Formation in Plants and Cuttings (MB Jackson, ed), Martinus Nijhoff Publishers, Dordrecht, the Netherlands, 111140

Lund ST, Smith AG, Hackett WP (1996) Cuttings of a tobacco mutant, rac, undergo cell division but do not initiate roots in response to exogenous auxin. Physiol Plant 97, 372-380

Mitsuhashi M, Shibaoka H, Shimokoriyama M (1969) Morphological and physiological characterization of IAA-less-sensitive and IAA-sensitive phases in rooting of Azukia cuttings. Plant Cell Physiol 10, 867874

Moncousin C, Ducreux G (1984) Activité peroxydasique et rhizogenèse dans le cas de Cynara scolymus $\mathrm{L}$ : évolution au cours de repiquages successifs de boutures cultivées in vitro. Comparaison avec de jeunes plantes issues de graines. agronomie 4, 105-111

Moncousin C, Favre JM, Gaspar T (1989) Early changes in auxin and ethylene production in vine cuttings before adventitious rooting. Plant Cell Tiss Org Cult 19, 235-242

Murray JR, Smith AG, Hackett WP (1994) Differential dihydroflavanol reductase transcription and anthocyan pigmentation in the juvenile and mature phases of ivy (Hedera helix L). Planta 92, 69-78

Noiton D, Vine JH, Mullins MG (1992) Effects of serial subculture in vitro on the endogenous levels of indole-3-acetic acid and abscissic acid and rootability in microcuttings of 'Jonathan' apple. Plant Growth Regul 11, 377-383

Pythoud F, Buchala AJ (1989) Peroxidase activity and adventitious rooting in cuttings of Populus tremula. Plant Physiol Biochem 27, 503-510

Sanchez MC, Smith AG, Hackett WP (1995) Localized expression of a proline-rich protein gene in juvenile 
and mature ivy petioles in relation to rooting competence. Physiol Plant 93, 207-216

Smith DL, Fedoroff NV (1995) LRP1, a gene expressed in lateral and adventitious root primordia of Arabidopsis. Plant Cell 7, 735-745

Torrigiani $P$, Altamura MM, Capitani F, SerafiniFracassini D, Bagni N (1989) De novo root formation in thin cell layers of tobacco: changes in free and bound polyamines. Physiol Plant 77, 294-301

Tripepi RR, Heuser CW, Shannon JC (1983) Incorporation of tritiated thymidine and uridine into adventitious-root initial cells of Vigna radiata. J Am Soc Hort Sci 108, 469-474

Van Der Krieken WM, Breteler H, Visser MHM, Mavridou D (1993) The role of the conversion of IBA into IAA on root regeneration in apple: introduction of a test system. Plant Cell Rep 12, 203-206

Vieitez J, Kingston DGI, Ballester A, Vieitez E (1987) Identification of two compounds correlated with lack of rooting capacity of chestnut cuttings. Tree Physiol 3, 247-255

Weigel U, Horn W, Hock B (1984) Endogenous auxin levels in terminal stem cuttings of Chrysantemum morifolium during adventitious rooting. Physiol Plant $61,422-428$

Woo HH, Hackett WP, Das A (1994) Differential expression of a chlorophyll $a / b$ binding protein gene and a proline rich protein gene in juvenile and mature phase of English ivy (Hedera helix). Physiol Plant 92, 69-78

Zimmerman RH, Hackett WP, Pharis RP (1985) Hormonal aspects of phase change and precocious flowering. In: Hormonal Regulation of Development. III. Role of Environmental Factors. Encyclopedia of Plant Physiology, New series, Vol 11 (RP Pharis, DM Reid, eds), Springer-Verlag, Berlin, Germany, 79-115 